\title{
Komunikasi Dakwah di Pesantren Terpadu Lembaga \\ Pemasyarakatan
}

https://doi.org/10.25008/wartaiski.v2i02.33

\author{
Siti L. Latifah ${ }^{1}$, Yasyifa F. Nursyamsi ${ }^{2}$, Hari R. Hakim ${ }^{3}$, Emil Permanasari ${ }^{4}$, Uwes Fatoni ${ }^{5}$ \\ Program Pascasarjana Prodi Komunikasi dan Penyiaran Islam UIN Sunan Gunung Djati \\ Jl. A.H. Natusion No. 105, Bandung - Indonesia \\ Email Korespondensi: lutfilatifahjaelani@gmail.com
}

\begin{abstract}
Abstrak
Tujuan penelitian ini untuk mengetahui aktivitas komunikasi dakwah dengan segala permasalahan yang terjadi pada pesantren terpadu At-Taubah di Lembaga Pemasyarakatan Klas II B. Cianjur. Metode yang digunakan dalam penelitian ini adalah metode deskriptif dengan pendekatan kualitatif. Teknik pengumpulan data dilaksanakan melalui observasi, wawancara, dokumentasi dan studi pustaka. Temuan penelitian ini adalah pesantren di dalam lembaga pemasyarakatan berbeda dengan pesantren yang berada di luar lembaga pemasyarakatan. Pesantren yang berada di luar lembaga pemasyarakatan menjadi tempat untuk belajar ilmuilmu agama, sedangkan pesantren di dalam Lembaga Pemasyarakatan selain tempat belajar ilmu-ilmu agaman juga menjadi pusat penyadaran para Warga Binaan, sebutan lain dari penghuni Lembaga Pemasyarakatan yang sedang menjalani hukuman pidana.
\end{abstract}

Kata Kunci : Komunikasi dakwah, Lembaga Pemasyarakatan, Pesantren, Warga binaan, Ilmu agama .

\begin{abstract}
The purpose of this study was to determine the activities of preaching communication with all the problems that occur in the integrated boarding school At-Taubah at Class II B Penitentiary, Cianjur. The method used in this research is descriptive method with a qualitative approach. Data collection techniques carried out through observation, interviews, documentation and literature study. The findings of this study are the pesantren inside the penitentiary are different from the pesantren that are outside the penitentiary. Pesantren outside prison are a place to study religious sciences, while pesantren inside Penitentiary in addition to places to study religious sciences are also a center for awareness of the Guided Residents, another term for prisoners who are serving criminal sentences.
\end{abstract}

Keywords: Da'wah communication, Correctional Institutions, Islamic Boarding Schools, Guided Residents, Religious Sciences.

\section{PENDAHULUAN}

Dakwah merupakan tugas mulia yang diperintahkan Allah dalam Alquran dan As-Sunnah untuk umat muslim dan muslimat yang berakal dan baligh, serta bagi semua manusia yang mengaku menghambakan diri kepada Allah SWT. Sebagai umat Nabi Muhammad SAW, umat muslim diwajibkan untuk melaksanakan dakwah.

Seperti definisi dakwah Ahmad Ghalwuy bahwa dakwah adalah menyampaikan pesan Islam kepada manusia di setiap waktu dan tempat dengan metode-metode dan media-media yang sesuai dengan situasi dan kondisi para penerima pesan dakwah (khalayak dakwah)". (Enjang dan Aliyudin,2009:8). Komunikasi pada dasarnya penyampaian pesan yang disengaja dari sumber terhadap penerima dengan tujuan mempengaruhi tingkah laku pihak penerima (Miller, 1966).

Komunikasi dakwah menyampaikan pesan-pesan keagamaan dalam berbagai tatanan agar jamaahnya terpanggil dan merasakan pentingnya nilai Islam dalam kehidupan, pada tatanan publik, dan memasyarakatkan nilai Islam diberbagai majelis, pesantren dan masjid (Ma'arif, 2009: 161).

Komunikasi dakwah adalah proses penyampaian informasi atau pesan dari seseorang atau sekelompok orang kepada seseorang atau sekelompok orang lainnya yang bersumber dari Alquran dan Hadist dengan menggunakan lambang-lambang baik secara verbal maupun nonverbal dengan 
e-ISSN: 2686-0724 - p-ISSN: 0853-4470 - Vol. 02, No. 02 (2019), pp. 74-60 tujuan untuk mengubah sikap, pendapat atau prilaku orang lain yang lebih baik sesuai ajaran Islam (Wahyu, 2010: 24).

Komunikasi dakwah berperan dalam penyampaian pesan-pesan dakwah dari seorang da'i terhadap mad'unya agar terjadi perubahan prilaku seorang mad'u menjadi lebih baik sehingga tercapainya tujuan dakwah, karena salah satu fungsi dari komunikasi dakwah adalah terjadinya perubahan terhadap objek dakwah tanpa ada paksaan melainkan melalui kesadaran hingga akhirnya bisa dipahami dan diamalkan.

Aktivitas dakwah hadir dilatar belakangi oleh perilaku manusia yang jauh dari fitrahnya, seperti halnya Allah SWT memerintahkan nabi Muhammad SAW berdakwah ketika Arab pada waktu itu berada dalam masa jahiliyah, sejarahnya mengatakan bahwa Arab sebelum Nabi Muhammad SAW datang tidak bermoral dan tidak mengakui Allah sebagai tuhannya, bahkan menjadikan patung atau berhala sebagai tuhannya. Maka dari itu Allah SWT mengutus Rasulullah SAW berdakwah untuk memperbaiki akhlak, menegakan tauhid pada masa Arab jahiliyah tersebut.

Salah satu lembaga dakwah Islam adalah sebuah pesantren, pada awal berdirinya pesantren merupakan sebuah lembaga dakwah Islam yang pertama didirikan oleh salah seorang walisongo yakni Syekh Maulana Malik Ibrahim untuk mentranformasi nilai-nilai Islam dan mendidik para santrinya. Seiring berjalannya waktu pesantren terus berkembang hingga tersebar di seluruh Indonesia.

Salah satu pesantren yang berdiri sebagai sarana transformasi nilai-nilai Islam adalah Pesantren Terpadu At-Taubah yang berdiri di sebuah Lembaga Pemasyarakatan, yaitu Lembaga Pemasyrakatan Klas II B Cianjur, merupakan salah satu tempat untuk melakukan pembinaan terhadap para Warga Binaan. Dari hasil observasi awal di Lembaga Pemasyarakatan Klas II B Cianjur didirikan khusus sebuah pesantren terpadu yang di beri nama Pondok Pesantren terpadu At-Taubah sebagai fasilitas dari Lembaga Pemasyarakatan untuk para Warga Binaan. Pesantren Terpadu At-Taubah menjadi salah satu pesantren yang berdiri dalam sebuah lembaga pemasyarakatan dan dijadikan pesantren Lapas percontohan oleh Lapas di Indonesia.

Dari uraian tersebut ada beberapa hal yang menarik untuk diteliti, diantaranya: pertama, biasanya pesantren adalah sebuah lembaga yang berdiri sendiri atau di dirikan oleh seorang Kyai, dan pesantren At-Taubah ini didirikan dalam sebuah Lembaga Pemasyarakatan. Kedua, dari hasil observasi awal bahwa pesantren terpadu At-Taubah ini menjadi pesantren lapas percontohan dan di jadikan studi banding untuk lapas lain di Indonesia, diantaranya yaitu Lembaga Pembinaan Khusus Anak (LPKA) kelas I Martapura Kalimantan Selatan, di dalamnya diresmikan pendirian pesantren dan diberi nama yang sama yaitu Pesantren At-Taubah. (Hasil wawancara di lapas Klas II B Cianjur, 20 Desember 2016 pukul 14.30 bersama Bapak Idrus Bagian Kepegawaian lapas Klas II B Cianjur).

Selain itu, Lembaga Pemasyarakatan Klas II A Kuningan Jawa Barat mengadakan studi banding yang dipimpin langsung oleh Kalapas Gumelar dan pejabat dari MUI dan DPRD Kabupaten Kuningan (Berita online, cianjurKINI.com). Selanjutnya Pesantren At-Taubah Lembaga Pemasyarakatan Klas II B Cianjur dikunjungi beberapa tamu dari mancanegara seperti Australia, Arab Saudi untuk sekedar kunjungan ke Pesantren terpadu dan memberikan apresiasi terhadap pesantren dengan memberikan dana untuk pembangunan pesantren. ( Hasil wawancara di sekertariat pesantren At-Taubah bersama pimpinan pesantren K.H Totoy Mukhtar Gojali selaku pimpinan pondok pesantren).

Pesantren At-Taubah selain dijadikan contoh oleh lapas lain juga mengundang perhatian berbagai media televisi swasta. Dari awal berdirinya pesantren Terpadu AT-Taubah, kegiatannya di liput langsung oleh beberapa media televisi swasta, di antaranya TV ONE dalam acara Damai 
Indonesiaku dan Hikmah, METRO TV dalam acara OASE Ramadhan, dan ANTV dalam acara Cakrawala.

Penelitian ini difokuskan pada komunikasi dakwah di pesantren terpadu At-Taubah lembaga pemasyarakatan Klas II B Cianjur. Dari hasil studi pustaka penelitian ini baru pertama kali dilakukan. Adapun yang menjadi tinjauan pustaka dalam penelitian ini adalah : penelitian Handi Supriadi (2014). Pembinaan Agama Islam Sebagai Upaya Pengurangan Terjadinya Pengulangan Tindak Pidana Bagi Narapidan Di Lapas Klas II B Cianjur. Setelah memahami hasil penelitian dari Handi Supriadi, peneliti mengetahui gambaran umum dakwah di pesantren terpadu At-Taubah lembaga pemasyarakatan Klas II B Cianjur. Pesantren tersebut terbukti berfungsi sebagai pembinaan agama Islam bagi warga binaan, yang merupakan tempat yang sama dengan apa yang peneliti teliti. Bedanya penelitian dari Handi Supriadi fokus kepada pembinaan agama Islam sedangkan penelitian yang peneliti lakukan lebih ke mendeskripsikan seluruh kegiatan komunikasi dakwah di pesantren terpadu At-Taubah Lembaga Pemasyarakatan Klas II B Cianjur.

Berikutnya penelitian dari Sindu Galba, dan Hary Waluyo (2005) yang berjudul pesantren sebagai wadah komunikasi di pesantren Suryalaya Tasikmalaya. Hasil penelitian ini menjelaskan bagaimana sebuah pesantren berfungsi sebagai suatu wadah komunikasi untuk santri yang ada di dalam pesantren tersebut, pesantren Suryalaya berhasil menjadi sebuah wadah komunikasi bagi santri dengan santri yang lainnya, santri dengan masyarakat setempat, dan santri dengan sang Kyai maupun pengasuh atau pengajar pesantren.

Dari penelitian terdahulu di atas dapat dilihat bahwa fungsi pesantren adalah sebagai wadah komunikasi. Ini juga berlaku di pesantren terpadu At-Taubah lembaga pemasyarakatan Klas II B Cianjur, sebelum dan sesudah didirikannya pesantren At-Taubah tersebut mengalami perubahan. Jika sebelumnya warga binaan yang ada di lembaga pemasyarakatan satu dengan yang lainnya tidak akur bahkan sering terjadi keributan antara kamar yang meresahkan, akan tetapi ketika sudah didirikan pesantren di dalam lapas tersebut membuat warga binaan satu dengan yang lainnya rukun. Bahkan dari penelitian yang dilakukan setelah hadirnya pesantren tersebut warga binaan hidup rukun terlihat signifikan, antar blok bahkan beberapa blok berkumpul bersama dan makan bersama, ngopi bersama. Ini menunjukan bahwa memang pesantren mempunyai fungsi sebagai wadah komunikasi bagi santri dengan santri lainnya, seperti hasil penelitian dari buku tersebut.

Penelitian lainnya dari Muljono Damopoli (2011) yang berjudul Pesantren Modern IMMIM Pencetak Muslim Modern dan rujukan yang terakhir dari buku Tradisi Pesantren (Studi Pandangan Hidup Kyai) yang di susun oleh Zamakshyari Dhofier (2011). Dari hasil kajian penelitian ini, peneliti mendapatkan berbagai teori yang memperkaya dan menguatkan teori penelitian khususnya teori tentang Pesantren.

Penelitian ini didasari dengan rumusan masalah bagaimana latar belakang didirikannya pesantren terpadu AT-Taubah Lembaga Pemasyarakatan Klas II B Cianjur, Bagaimana aktivitas dakwah di pesantren terpadu AT-Taubah lembaga pemasyarakatan Klas II B Cianjur, dan bagaimana Pesantren Terpadu At-Taubah menghadapi kendala dalam aktivitas dakwah yang dilaksanakan.

\section{KERANGKA TEORI}

Penelitian ini diawali oleh asumsi dasar bahwa dakwah merupakan sebuah tugas suci yang di perintahkan oleh Allah SWT untuk umat muslim, menyeru kepada amar ma'ruf nahyi munkar, yaitu ajakan untuk jalan yang di ridhai oleh Allah SWT dan ajakan untuk meninggalkan seluruh larangan yang Allah perintahkan. Semua orang bisa melakukan dakwah dengan cara dan kemampuan yang dimilikinya. Firman Allah dalam Alquran Surat Ali Imrah: 110. 
e-ISSN: 2686-0724 - p-ISSN: 0853-4470 - Vol. 02, No. 02 (2019), pp. 74-60 Kamu adalah umat yang terbaik yang dilahirkan untuk manusia, menyuruh kepada yang ma'ruf, dan mencegah dari yang munkar, dan beriman kepada Allah. Sekiranya ahli kitab beriman, tentulah itu lebih baik bagi mereka, di antara mereka ada yang beriman, dan kebanyakan mereka adalah orang-orang yang fasik.

Dalam ayat tersebut Allah tidak memilah dan memilih siapa saja yang wajib melakukan dakwah, akan tetapi Allah mewajibkan semua umat Muslim untuk melakukan dakwah. Komunikasi pada dasarnya penyampaian pesan yang disengaja dari sumber terhadap penerima dengan tujuan mempengaruhi tingkah laku pihak penerima (Miller,1966).

Komunikasi dakwah menyampaikan pesan-pesan keagamaan dalam berbagai tatanan agar jamaahnya terpanggil dan merasakan pentingnya nilai Islam dalam kehidupan, pada tatanan publik, dai memasyarakatkan nilai Islam diberbagai majelis, pesantren dan masjid (Ma'arif, 2009: 161).

Dalam jurnal komunikasi dikutip dari buku psikologi dakwah Ahmad Mubarok mengungkapkan bahwa kegiatan dakwah adalah kegiatan komunikasi, dimana da' $i$ mengkomunikasikan pesan dkepada mad'u baik secara perseorangan maupun kelompok (Eva, 2016: 35). Komunikasi dan dakwah bersifat simbiotik jika komunikasi dikaitkan dengan dakwah maka apa yang disampaikan penceramah atau $d a{ }^{\prime} i$ sebagai komunikator dapat dipahami sepenuhnya oleh mad'u sebagai komunikan (Markama, 2014 : 144).

Komunikasi dakwah berperan dalam penyampaian pesan-pesan dakwah dari seorang da' $i$ terhadap mad'unya agar terjadi perubahan prilaku seorang mad'u menjadi lebih baik sehingga tercapainya tujuan dakwah, karena salah satu fungsi dari komunikasi daakwah adalah terjadinya perubahan terhadap objek dakwah tanpa ada paksaan melainkan meelalui kesadaran hingga akhirnya bisa dipahami dan diamalkan.

Aktivitas dakwah hadir dilatar belakangi oleh perilaku manusia yang jauh dari fitrahnya, seperti halnya Allah SWT memerintahkan nabi Muhammad SAW berdakwah ketika Arab pada waktu itu berada dalam masa jahiliyah, sejarahnya mengatakan bahwa Arab sebelum Nabi Muhammad SAW datang tidak mempunyai moral dan tidak mengakui Allah sebagai tuhannya, bahkan menjadikan patung atau berhala sebagai tuhannya. Maka dari itu Allah SWT mengutus Rasulullah SAW berdakwah untuk memperbaiki akhlak, menegakan tauhid pada masa arab jahiliyah tersebut.

Aktivitas dakwah adalah segala sesuatu yang berbentuk aktivitas atau kegiatan yang dilakukan dengan sadar yang mengajak manusia kejalan yang mulia di sisi Allah SWT, serta meluruskan perbuatan-perbuatan yang menyimpang dari ajaran-ajaran Islam (Shofi, 2010:13).

Dalam menjalankan aktivitas dakwah akan menemukan berbagai kendala, baik dari segi objek dakwah maupun pesan dakwah, karena setiap objek dakwah itu berbeda, dari mulai adat budaya, pemahaman, hingga masalah kehidupan yang dihadapi, sehingga setiap objek dakwah memerlukan perlakuan yang berbeda. Maka dari itu seorang pegiat dakwah harus memerhatikan unsur-unsur yang ada dalam dakwah.

Unsur-unsur yang perlu di perhatikan atau di kaji dalam pelaksanaan dakwah adalah segala sesuatu yang berhubungan dengan terlaksananya aktivitas dakwah, di mulai dari siapa yang berdakwah dan siapa yang di dakwahi, bagaimana kondisi yang di dakwahi, cara apa yang tepat untuk mendakwahi, solusi yang tepat untuk permasalahan yang di hadapi oleh objek dakwah dan segala hal yang berhubungan dengan terlaksananya aktivitas dan tujuan dakwah.

Enjang A.S dan Aliyudin (2009: 73) menyatakan bahwa dakwah dalam prosesnya akan melibatkan unsur-unsur (rukun) dakwah yang terbentuk secara sistematik, artinya antara unsur yang satu dengan unsur yang lainnya saling berkaitan. Adapun unsur dakwah yang beliau rumuskan 
terdapat enam unsur utama (pokok), yaitu $d a$ ' $i$ (subjek dakwah), maudu' (materi dakwah) di sebut juga pesan dakwah, ushlub (metode dakwah), wasilah (media dakwah), mad'u (objek dakwah), dan tujuan dakwah.

Unsur satu dengan unsur yang lainnya saling berkaitan, ketika semua unsur diperhatikan dan disesuaikan dengan objek dakwah maka segala kendala yang ada dalam pelaksanaan aktivitas dakwah akan terselesaikan, dan tercapainya tujuan dakwah (Ismail, Abidin, \& Fatoni, 2018).

Proses kegiatan dakwah tidak hanya dilakukan dengan ceramah saja, tetapi bisa melalui perkataan, perbuatan, tulisan. Adapun dakwah melalui perkataan seperti halnya yang di lakukan para ulama, kyai, ustad, dengan ceramah di masjid ataupun di pengajian dan di kegiatan-kegiatan PHBI (Peringatan Hari Besar Islam). Dakwah dengan perbuatan yaitu dengan cara kita berakhlak mulia. Dakwah melalui tulisan dengan menulis buku, ataupun karya ilmiah yang berhubungan dengan pesanpesan dakwah. Dengan begitu tidak membatasi seorang muslim untuk melaksanakan kewajibannya dalam berdakwah, serta tidak memberikan beban dakwah seutuhnya kepada para ulama.

Menurut Aep Kusnawan dalam dakwah terdapat dua dimensi besar, pertama,mencakup penyampaian pesan kebenaran, yaitu dimensi kerisalahan (bi ahsan al-qawl), serta kedua, mencakup pengaplikasian nilai kebenaran yang merupakan dimensi kerahmatan (bi ahsan al-amal) (Kusnawan, 2009 : 16). Sedangkan menurut Uwes Fatoni (2018: 2019) dakwah merupakan proses untuk mengajak umat menuju kondisi yang lebih baik.

Enjang As dan Hajir Tajiri (2009: 12) menyatakan secara sederhana kegiatan dakwah ini merupakan proses mengajak manusia kepada al-Islam yang di lakukan dengan lisan atau tulisan ( dakwah bil al lisan dan bi al qalam), juga bisa dengan perbuatan (dakwah bi al hal) atau aksi sosial Islam (bi ahsan al amal), dan menggorganisir serta mengelola kegiatan mengajak (bi al lisan, bi al qalam, dan bi al hal) dalam bentuk lembaga-lembaga Islam sebagai lembaga dakwah yang melakukan sistematisasi tindakan, kordinasi, sinkronisasi, dan integrasi program kegiatan dengan sumber daya dan waktu yang tersedia untuk mencapai sasaran dan tujuan dakwah Islam.

Salah satu lembaga dakwah adalah pesantren, pesantren merupakan sebuah lembaga dakwah Islam yang sudah sejak lama berdiri di Indonesia yang berfungsi sebagai sarana untuk mentransformasi nilai-nilai Islam dari seorang yang di nyatakan mempunyai ilmu agama yang tinggi atau luas, yang biasanya di sebut dengan kyai kepada santrinya.

Amin Haedari mengungkapkan bahwa fungsi pesantren adalah sebagai institusi pendidikan, lembaga dakwah, bimbingan kemasyarakatan dan perjuangan (Amin dan Hanif, 2004: 15). Pesantren selain dinyatakan sebagai lembaga dakwah juga dinyatakan sebagai lembaga pendidikan Islam tradisional yang telah berdiri lama dan sebagai pusat penyebaran agama Islam di Indonesia. Dalam tradisi pesantren metode utama sistem pengajaran di lingkungan pesantren menggunakan sistem bandongan atau seringkali di sebut weton. Dalam sistem ini sekelompok murid mendengarkan seorang guru yang membaca, menerjemahkan, menerangkan (Dhofier, 2011:54).

Pesantren bisa dikatakan sebuah pesantren jika memiliki elemen-elemen pesantren. Pondok, masjid, santri, pengaajaran kitab Islam klasik dan kyai adalah lima elemen dasar tradisi pesantren (Dhofier, 2011: 79).

Pondok merupakan tempat tinggal santri yang sederhana, masjid selain sebagai tempat melaksanakan ibadah mahdah di dalam pesantren juga digunakan sebagai tempat pembelajaran para santri, santri adalah orang yang belajar Islam di pesantren dan kitab klasik adalah pelajaran-pelajaran yang di pelajari dan gurunya adalah kiai.

Pada dasarnya pesantren merupakan lembaga dakwah Islam yang berfungsi sebagai alat untuk mentranformasi nilai-nilai Islam dari kyai kepada santrinya, Pesantren merupakan lembaga pendidikan yang betujuan untuk tafaqquh fiddin (memahami agama) dan membentuk moralitas 
e-ISSN: 2686-0724 - p-ISSN: 0853-4470 - Vol. 02, No. 02 (2019), pp. 74-60 melalui pendidikan. Sampai sekarang, pesantren pada umumnya bertujuan untuk belajar agama dan mencetak pribadi Muslim yang kaffah yang melaksanakan ajaran Islam secara konsisten dalam kehidupan sehari-hari.

Sekalipun disebut sebagai lembaga dakwah Islam yang berfungsi sebagai transformasi nilainilai Islam tidak menjamin pesantren dan seluruh isinya slalu hidup berdampingan dengan rukun, akan tetapi Kegiatan pesantren yang terus-menerus dilaksanakan cenderung akan menimbulkan konflik.

Menurut Shulthone Masyhud (2005) kemungkinan konflik yang akan muncul di pesantren adalah: (1) konflik antar guru atau ustadz, (2) konflik antara ustadz dan santri, (3) konflik antarsantri, (3) konflik antar lembaga pesantren dan lingkungan, (4) konflik antara pengurus dan pengasuh atau kiai. Konflik ini akan muncul karena adanya rangsangan yang datang dari diri sendiri maupun orang lain. Rangsangan tersebut kemudian menciptakan seseorang untuk melakukan sesuatu tindakan yang tidak menyenangkan terhadap orang lain.

Hal-hal yang menjadi pemicu bermacam-macam konflik tersebut dapat meliputi: (a) prasangka buruk, (b) kesalahpahaman; (c) sipat keras kepaala atau egois; (d) rasa peka atau mudah tersinggung; (e) perbedaan interpretasi; (f) perbedaan cara atau metode atau pendekatan; (g) ketergantungan dalam melaksanakan pekerjaan; (h) perbedaan kepentingaan atau kebutuhan (i) perbedaan latar nilai budaya; (j) perbedaan tujuan; (k) persaingan memperebutkan status atau posisi; (1) berkurangnya sumbersumber tertentu, seperti kekuasaan, pengaruh, uang, ruang, waktu, popularitas, dan posisi; (m) dan lain-lain.

Sulthone Masyhud (2005) memberikan solusi dalam konflik yang biasa terjadi di pesantren dengan Cara melalui beberapa pendekatan, diantaranya: (a) pendekatan struktural, dimana setiap penanganan konflik harus dikembalikan kepada rantai komando organisasi pesantren. (b) pendekataan kelompok, dimana kelompok yaang lebih dominan memprakarsai penyelesaian konflik dengan menyiapkan solusi yang dapat diterima semua komponen pesantren.(c) bargaining antar pelaku konflik (kompetitor) dimana setiap konflik dibawa kedalam suatu musyawarah untuk mencari pemecahan yang tepat. (d) merubah hubungan organisasional. (e) pendekatan pemecahan masalah. Pendekatan ini lebih fokus kepada kontroversi itu sendiri dan tidak ada keperpihakan kepada pihakpihak yang terlibat dalam konflik. (f) meningkatkan komunikasi antar unit, dalam organisasi pesantren terdapat unit-unit organisasi yang biasa merancaang dan melaksanakan program sendirisendiri. Untuk menghindari kesimpang siuran informasi antar unit tersebut perlu dibangun dan dikembangkan hubungan departemental yang kuat.

Pesantren biasanya adalah sebuah lembaga dakwah yang berdiri sendiri, atau di dirikan khusus oleh seorang kyai. Seperti hal nya sejarah pertama pendirian pesantren di Indonesia yaitu di dirikan oleh salah satu wali songo yang bernama syeikh Maulana Malik Ibrahim atau Sunan Gresik (W. 1419) yang merupakan orang pertama yang membangun pesantren sebagai tempat mendidik dan menggembleng santrinya. Dalam buku Manajemen pondok pesantren Sulthone Masyhud dan Khusnurdilo mengatakan bahwa kepemilikan pesantren bersifat individual atau keluarga bukan komunal. (Masyhud dkk, 2005:15).

Akan tetapi di lembaga pemasyarakatan Klas II B Cianjur, yang merupakan rumah binaan dan tahanan bagi para masyarakat yang di nyatakan bersalah secara hukum karena tindak kriminal, didirikan khusus sebuah pesantren di dalamnya sebagai sarana dan lembaga dakwah untuk para santri yang berada dalam lapas (warga binaan). Adapun lapas sendiri adalah tempat untuk melaksanakan pembinaan Narapidana dan Anak Didik Pemasyarakatan. (UU RI No.12 tahun 1995 tentang pemasyarakatan). 
Berdirinya sebuah pesantren di lembaga pemasyarakatan menjadi lembaga dan sarana dakwah untuk para pegiat dakwah agar mampu membimbing para santri warga binaan menjadi warga yang taat dan dapat di terima kembali oleh masyarakat pada umumnya. Dari pengertian dakwah secara etimologi yang telah di sebutkan di atas menunjukan arti dakwah secara umum, yaitu mengajak, menyeru, mengundang manusia, akan tetapi ajakan disini masih bersifat umum bisa saja ajakan menuju jalan yang benar atau sebaliknya.

Aktivitas menurut kamus besar bahasa Indonesia adalah keaktifan, kegatan-kegiatan, kesibukan atau juga berarti kerja atau salah satu kegiatan kerja yang dilaksanakan tiap bagian dalam tiap suatu organisasi atau lembaga. (KBBI, 2004:17).

Dari penjelasan di atas bisa diketahui bahwa aktivitas dakwah adalah segala sesuatu yang berbentuk aktivitas atau kegiatan yang dilakukan secara sadar yang mengajak manusia ke jalan yang mulia di sisi Allah SWT, serta meluruskan perbuatan-perbuatan yang menyimpang dari ajaran-ajaran Islam.

\section{METODE PENELITIAN}

Penelitian ini menggunakan metode deskriptif, karena dengan metode tersebut bisa mendeskripsikan atau menggambarkan secara sistematis, aktual dan akurat kegiatan-kegiatan dakwah serta hambatan dan penyelesaiannya yang berada dalam Pesantren Terpadu At-Taubah. Metode yang di gunakan dalam penelitian ini adalah metode deskriptif dengan pendekatan kualitatif. Metode ini dapat menggambarkan fenomena komunikasi dakwah dan hambatannya yang terjadi di Pesantren Terpadu At-Taubah Lembaga Pemasyarakatan Klas II B Cianjur.

\section{HASIL PENELITIAN}

Pesantren terpadu At-Taubah yang berdiri di lembaga pemasyarakat II B Cianjur merupakan wujud dari pembinaan yang wajib dilakukan terhadap warga binaan, pada dasarnya pembinaan di sebuah lembaga pemasyarakatan itu ada dua, pertama pembinaan kepribadian dan pembinaan kemandirian, pembinaan kepribadian merupakan pembinaan yang berhubungan dengan rohani atau spiritual warga binaan, sedangkan pembinaan kemandirian merupakan pembinaan yang berhubungan dengan skil atau bakat yang harus dimiliki oleh warga binaan ketika keluar agar mempunyai bekal untuk melanjutkan hidup ketika keluar dari Lapas.

Wujud dari pembinaan kepribadian di Lembaga Pemasyarakatan Klas II B Cianjur yaitu dengan didirikannya sebuah pesantren terpadu yang diberi nama Pesantren Terpadu At-Taubah. Sebelum adanya pesantren pembinaan di Lapas Klas II B Cianjur dilakukan hanya satu kali dalam seminggu itupun hanya ceramah dari kepolisian atau penyuluh dari departemen agama.

Sebelum hadirnya Pesantren Terpadu At-Taubah keadaan warga binaan di Lapas Klas II B Cianjur terpandang meresahkan karena keributan yang terjadi antar warga binaan menjadi sesuatu hal yang biasa, Warga binaan yang lama dan kuat menyiksa warga binaan yang baru masuk, warga binaan yang dijenguk dan dibawakan makanan dirampas oleh warga binaan lain yang merasa paling kuat dan ditakuti, ketika ada warga binaan yang mau melaksanakan shalat subuh terdengar cipratan air sedikitpun dimarahi, dan masih banyak lagi keributan yang meresahkan. Selain itu ditemui banyak sekali warga binaan yang beragama Islam tidak bisa melaksanakan ibadah wajib seperti shalat, bahkan ibadah dijadikan lecehan ketika melaksanakan shalat banyak warga binaan yang tidak mempunyai wudu bahkan membuang angin ketika shalat, dan itu biasa mereka lakukan dan tidak membatalkan shalatnya malah terus melanjutkan shalat. Mereka lakukan atas dasar ketidaktauan dan atas dasar kebiasaan. Selain itu juga hampir $70 \%$ warga binaan tidak bisa membaca Alquran. 
e-ISSN: 2686-0724 - p-ISSN: 0853-4470 - Vol. 02, No. 02 (2019), pp. 74-60

Pada waktu itu lapas dan sebagian warga binaan karena merasa prihatin dengan kondisi warga binaan yang bisa disebut meresahkan dan pembinaan yang berada di lapas Cianjur yang kurang efektif maka pihak lapas berinisiatif mencoba melaksanakan kegiatan dakwah dengan mengadakan peringatan Maulid Nabi pada hari Senin tanggal 13 Febuari 2012 di Lembaga Pemasyarakatan Klas II B Cianjur dan mengundang aparatur pemerintahan Cianjur, diantaranya Bupati Kab. Cianjur, ketua DPRD Kab.Cianjur, dan Ketua MUI Kab. Cianjur, pada saat peringatan Maulid Nabi belum mengarah kepada pendirian sebuah pesantren.

Ketika pihak Lapas yang dipimpin oleh Kalapas sendiri bersilaturahmi kepada MUI Kabupaten Cianjur untuk menindak lanjuti permintaan untuk bantuan peningkatan program pembinaan keagamaan di Lapas, Kalapas berbicara kepada MUI khususnya pak Totoy "Pak Haji tolong bantu kami disini biar warga kami disini menjadi masyarakat yang Islami”" (Cerita sejarah terbentuknya pesantren di lapas yang diceritakan oleh Pimpinan Pesantren terpadu At-Taubah di sekertariat PP AlIntiqol, pesantren beliau).

Maka dengan sendirinya "Gayung Bersambut" kedua Lembaga tersebut memiliki pemikiran dan keinginan yang sama untuk mengefektifkan program pembinaan keagamaan kepada warga binaan. Dan akhirnya sampailah kepada keputusan bersama perlunya dibentuk Pesantren Terpadu AtTaubah Lapas Klas II B Cianjur.Tidak lama kemudian maka diterbitkanlah Surat Keputusan Bersama antara Ketua MUI Kabupaten Cianjur dengan Kepala Lapas Klas II B Cianjur tentang Pesantren Terpadu At-Taubah Lapas Klas II B Cianjur.

Surat Keputusan bersama antara Kepala Lembaga Pemasyarakatan Klas II B Cianjur dan Ketua MUI Kab. Cianjur di tandatangani pada tanggal 1 Mei 2012 sekitar pukul 09:00 WIB di ruang Kepala Lembaga Pemasyarakatan Klas II B Cianjur dan sekaligus merencanakan tanggal peresmian Pesantren Terpadu yang di sepakati hari Rabu tanggal 9 Mei 2012 sekitar pukul 10:00 wib serta pembuatan proposal kegiatan untuk mendapat dukungan dari Bupati Kab. Cianjur, Surat Keputusan Bersama tersebut mulai berlaku sejak tanggal di tetapkan yaitu tanggal 7 Mei 2012.

Dari sejarah panjang terbentuknya pesantren terpadu At-Taubah yang berada dalam Lembaga Pemasyarakatan Klas II B Cianjur ini mengungkapkan betapa keshalihan atau kesadaran para warga binaan akan tercapai ketika mempunyai wadah dan alat khusus dalam pencapaiannya, maka pendirian Pesantren dan Kyai menjadi jalan keluar untuk keresahan yang terjadi dalam Lembaga Pemasyarakatan yang disebabkan oleh para Warga Binaan.

Sejarah mencatat bahwa para Kyai telah memberikan sumbangan kepada bangsa Indonesia sejak dulu. Sebagai pribadi, ia melaksanakan dakwah di masyarakat, sebagai pimpinan pesantren, ia membimbing masyarakat untuk mandiri dan memmeroleh kemajuan dalam berbagai bidang sehingga mereka dapat memperoleh penerangan batin. (Ma'arif, 2009:162).

Pelaksanaan Kegiatan Dakwah dengan dimensi kerisalahan (biahsan al-qawl), diantaranya : Tabligh erupakan bentuk kegiatan dakwah dengan bersifat masal dan insidental dari seorang mubaligh kepada mubalagh yang jumlahnya banyak dengan cara Khitobah yaitu seperti ceramah, khitabah melalui tulisan atau i'lam melalui media Televisi ataupun Internet. Pertama, Kegiatan tabligh melalui Khitobah.

Kegiatan dakwah dengan bentuk Tablig melalui Khitobah itu ada dua, yaitu Khitabah Diniyah dan Khitabah Ta'siriyah. Adapun kegiatan dakwah dengan bentuk Tabligh melalui Khitobah Ta'siriyah adalah Kegiatan pesantren pagi hari Kegiatan rutin pesantren harian ini dilakukan setiap hari Senin, Selasa, Rabu, dan Kamis dimulai dari pukul 08.00-10.00 WIB, yang diawali dengan shalat duha berjamaah di Masjid jami At-Taubah setelah itu masuk kelas masing-masing untuk melakukaan pembelajaran atau kegiatan pesantren. 
Kegiatan dakwah ini dibimbing oleh asatid yang berjumlah 32 orang dan setiap asatid memegang satu kelas, kecuali kelas santriawati karena hanya ada satu kelas jadi dibimbing oleh 4 (empat) asatid atau ustadzah. Dalam aktivitas dakwah ini pembelajarannya disesuaikan dengan tingkatan dan kemampuan santri atau warga binaan, yang telah dijelaMan diatas.

Setiap hari jadwal pelajaran berbeda, jadwal hari Senin yaitu Alquran dan Tauhid, Selasa Istigosah, Rabu Alquran dan Fiqh dan Kamis Alquran dan Tarikh Islam. Dalam pembelajaran pesantren tidak memberikan kurikulum yang baku kepada asatid untuk diajarkan kepada santri, tapi pesantren hanya memberikan jadwal umum saja, karena tujuan utama dari pesantren ini bukan penekanan pembelajaran akan tetapi lebih kepada penyadaran.

Tafsir Alquran dikhususkan untuk Palkam (Kepala Kamar) dan Korpe (Korp Pegawai) karena mereka tidak mengikuti aktivitas harian pesantren seperti yang lainnya maka dari itu diadakan pengajian khusus yang jadwalnya setiap hari Sabtu pagi. Mereka tidak mengikuti Megiatan pesantren sebagaimana yang lain dengan alasan Palkam merupakan kepala kamar yang harus menjaga kamar ketika santri yang lain sedang melaksanakan aktivitas pesantren sedangkan Korpe mereka harus melaksanakan pekerjaan yang telah ditugaskan, dan itu merupakan kebijakan.

Peringatan hari besar islam (PHBI) rutin dilakukan di Pesantren Terpadu At-Taubah diantaranya peringatan Maulid Nabi Muhammad SAW dan peringatan Isra Mi'raj. Adapun kegiatan dakwah dengan bentuk tabligh melalui Khitobah diniyah adalah : khutbah jumat yang diikuti oleh seluruh santri atau Warga Binaan dan petugas khutbahnya dari pegawai Lapas atau para asatid yang sudah dijadwalkan. Kemudian Khutbah idul fitri, khutbah idul adha, khutbah istisqo.

Kedua Irsyad, yaitu Kegiatan dakwah dalam bentuk irsyad diantaranya adalah : Kegiatan Pesantren Malam Hari. Kegiatan pesantren yang rutin dilakukan setiap malam diantaranya adalah membaca Alquran, qiyamul lail, shalat wajib berjamaah. Peraturan lapas yang menyatakan bahwa setelah pukul 17.00 WIB Warga Binaan wajib memasuka sel masing-masing menjadikan kegiatan pesantren pada malam hari terbagi ke dalam dua kelompok, pertama untuk 170 orang santri atas kebijakan Kalapas diperbolehkan melaksanakan kegiatan pesantren di luar kamar, dan kedua bagi santri yang tidak memiliki izin dan kebijakan dari Kalapas untuk melaksanakan kegiatan pesantren di luar lapas maka di perkenankan melaksanakan kegiatan keagamaan di kamar masing-masing.

Kegiatan 170 santri atau warga binaan khusus yang diberikan kebijakan melaksanakan kegiatan pesantren di luar sel di malam hari. Kepala Lembaga Pemasyarakan Bapak Yunianto memberikan kebijakan khusus kepada 170 santri yang telah diseleksi untuk melaksanakan kegiatan pesantren di luar kamar pada waktu malam hari dengan alasan bahwa di lapas itu ada pesantren dan masjid, kegiatan pesantren harus terus menerus dilaksanakan dan masjidpun tidak boleh sepi harus terus ada yang mengisi, sehingga kalapas mengeluarkan kebijakan untuk 170 orang santri diperbolehkan melaksanakan kegiatan pesantren di luar lapas. Adapun kegiatan yang dilaksanakan oleh santri tersebut adalah melaksanakan shalat berjamaah Magrib, Isya dan Subuh kemudian melaksanakan Kiyamul lail atau shalat malam.

Ungkapan kepala Lapas ketika di wawancarai :

"sebetulnya begini, sekitar jam lima narapidana harus sudah masuk kedalam sel karena kita ber background pesantrennya itu tidak ingin terhenti sehingga masjid itu harus terisi terus, di pilihlah beberapa orang itu untuk mengisis masjid, yang lainnya tetap berjamaah, pelaksanaan shalat sehingga masjidnya tidak mati, dimana tempat yang masjidnya terisi akan berkah” ( Wawancara dengan Kalapas Bpk. Yunianto di Ruang kepegawaian lapas pada tanggal 3 April 2017). 
e-ISSN: 2686-0724 - p-ISSN: 0853-4470 - Vol. 02, No. 02 (2019), pp. 74-60

Kegiatan Riyadhoh yang dilakukan rutin setiap minggu yaitu pada setiap malam Jum'at setelah magrib di masjid At-Taubah akan tetapi berbeda dengan istigosah, Riyadoh hanya dilakukann oleh \pm 170 orang santri atau warga binaan itupun santri yang sudah mendapatkan izin dan kebijakan dari Kalapas, karena sebenarnya pukul 17.00 seluruh warga binaan wajib tinggal di dalam sel hingga pagi sekitar pukul 08.00. WIB akan tetapi karena kebijakan Kalapas dengan alasan adanya pesantren dan masjid yang kegiatannya tidak boleh terhenti jadi sebagian santri yang terpilih bisa mengikuti pelaksanaan Riyadoh di Masjid AT-Taubah.

Istigosah dilakukan rutin dalam satu minggu sekali yaitu pada hari Selasa, setelah pelaksaan shalat dhuha bersama, seluruh santri melaksanakan kegiatan istigosah, istigosah merupakan salah satu cara penyadaran untuk para warga binaa, karena dalam kegiatan istigosah mengucapkan kalimatkalimat toyyibah dan di tuntun untuk khusu bertaubat dan berdoa kepada Allah SWT dipimpin oleh Mama Lapas langsung.

Shalat Duha berjamaah dilaksanakan setiap hari oleh seluruh warga binaan, sebelum memulai kegiatan pesantren yang lain seluruh warga binaan diwajibkan melaksanakan shalat berjamaah. Jadwal shalat duha berjamaah setiap hari pada pukul 08.00 WIB.

Pelaksanaan kegiatan dakwah dengaan dimensi keerahmatan atau bi ahsan al-amal diantaranya adalah Tadbir. Adapun kegiatan dakwah dengan Tadbir diantaranya : Pengelolaan zakat fitrah. Sebelum hadirnya pesantren di Lembaga Pemasyarakatan Klas II B Cianjur pelaksanaan zakat fitrah tidak di laksanakan di pesantren akan tetapi dilaksanakan oleh keluarganya masing-masing dan itupun ada yang melaksanakan ada yang tidak, akan tetapi setelah hadirnya pesantren di Lembaga pemasyarakatan II B Cianjur seluruh santri melaksanakan zakat fitrah. Pesantren memfasilitasi para santri untuk mengeluarkan zakat, jadi setiap santri zakatnya di kelola oleh Pesantren dengan cara santri menyerahkan zakat fitrah ke asatid masing-masing klas, dari asatid dikumpulkan di pesantren karena pesantren menjadi UPZ (Unit Pengelola Zakat ).

Seluruh santri yang beragama Islam melaksanakan zakat fitrah sekalipun santri itu tidak mempunyai uang untuk melaksanakan zakat fitrah, akan tetapi karena kekeluargaan yang di bangun oleh pesantren berhasil sehingga santri yang tidak memiliki biaya untuk melaksanakan zakat maka di bantu oleh santri lainnya, istilahnya zakat firahnya di bayarkan sama santri lainnya. Selain itu UPZ Pesantren At-Taubah juga menjadi UPZ terbaik di Kabupaten Cianjur dan mendapatkan penghargaan, seperti yang peneliti temua dalam melaksanakan wawancara bersama pimpinan pesantren, beliau mengatakan bahwa :

"zakat fitrah dikelola sama asatid setiap klas sehingga pesantren menjadi UPZ dan jadi terbaik. Semua melaksanakan zakat firah yang tidak memiliki uang ya di zakatan sama temennya, dibayarin" (Wawancara bersama pimpinan pesantren terpadu Bpk K.H Totoy Mukhtar GozalI sabtu 8 April 2017, pukul 21. 10 WIB Sekertariatan PP AL-Intiqol).

Kegiatan lainnya adalah Pencetakan Dai. Tujuan utama dari didirikannya pesantren memang penyadaran bagi para santri warga binaan akan tetapi lebih dari itu seiiring berjalannya waktu kegiatan dakwah dipesantren terus berkembang dan lebih dari itu bukan hanya penyadaran akan tetapi banyak warga binaan khususnya warga binaan di kelas eksekutive yang disediakan menjadi badal bagi asatid dan terbiasa menjadi badal atau pengganti, ketika keluar dari Lapas bercita-cita ingin melanjutkan dan menjadi ustad atau dai diluar, seperti ungkapannya Nuroni Syahroni ketika diwawancara :

"Masa hukuman saya disini tinggal satu tahun, ya saya juga insyaAllah ketika keluar dari sini akan melanjutkan dan ada keinginan bisa berdakwah, dapat bekel dari sini "( Hasil wawancara 
dengan Nuroni Syahroni seorang warga binaan/santri pada Selasa 04 April 2017 di Sekertariat Pesantren)

Pembinaan bagi warga binaan non muslim. Di dirikannya pesantren terpadu At-Taubah merupakan wujud perkembangan dari kewajiban lapas terhadap pembinaan kepribadian warga binaan dan mayoritas warga binaan di LembagaPemasyarakatan II B Cianjur adalah beragama Islam dan warga binaan yang beragama non muslim menjadi minoritas, akan tetapi bukan berarti warga binaan non muslim tidak mendapatkan pembinaan. Pembinaan untuk warga binaan non muslim diadakan satu minggu dua kali yaitu pada hari Rabu dan Sabtu dengan mendatangkan para pendeta dari luar, pihak lapas bekerjasama dengan Badan Kerja Sama Antar Gereja (BKSAG) Kab. Cianjur dan Gereja Batel Bandung yang dilaksanakan setiap hari Rabu dan Sabtu.

Tujuan dakwah adalah mengembalikan manusia ke pada fitrahnya, yaitu manusia yang menjalankan segala perintah dan larangan Allah SWT yang telah diterangkan dalam Alquran dan AsSunnah melalui kegiatan dakwah, akan tetapi dalam setiap kegiatan-kegiatan dakwah yang dilakukan tidak akan berjalan mulus dan selalu dihampiri oleh masalah, baik masalah dari mad'u sebagai objek dakwah, da'i sebagai subjek dakwah, maudhu ataupun media dakwah. Seperti halnya permasalahan yang dihadapi dalam kegiatan dakwah di pesantren terpadu At-Taubah Lapas II B Cianjur. Masalah dakwah di Pesantren Terpadu At-Taubah di rumuMan kedalam beberapa bagian, diantaranya : Masalah Pendanaan.

Jumlah santri atau warga binaan keseluruhan adalah 744 orang dengan jumlah kelas sebanyak 26 kelas, setiap kelas di bina oleh satu asatid kecuali kelas wanita yang dibina oleh empat asatid, dalam satu minggu asatid mendatangi pesantren sebanyak 3 kali karena kegiatan pesantren dalam kelas satu minggu hanya 3 kali pertemuan, yaitu pada hari Senin, Rabu dan Kamis, setiap satu kali kehadiran asatid diberikan uang transport sebesar Rp. 25.000, karena dalam satu minggu pertemuan 3 kali maka dalam satu bulan asatid melaksanakan 12 kali pertemuan di kelas. Jika dalam satu bulan 12 kali pertemuan dengan biaya transport 25.000 maka perbulan setiap satu asatid mendapatkan Rp. 300.000, jika jumlah asatid 33 orang maka pesantren memerlukan \pm Rp.9.900.000 per bulan untuk membiyayai asatid yang datang ke pesantren, belum biaya alat tulis untuk melaksanakan pembelajaran pesantren.

Solusi Lapas II B Cianjur bekerjasama dengan Pemerintah Kabupaten Cianjur Dan MUI Kab. Cianjur. Berawal dari sejarah berdirinya pesantren, ketika ada keresahan dari petugas lapas dan sebagiaan wargga binaan tentang kondisi warga binaan di lapas, maka pihak lapas meminta bantuan kepada peemerintah kabupaten Cianjur dan pihak MUI untuk melakukan pembinaan di peesantren, hingga akhirnya atas kerjasama pihak lapas, Pemerintah dan MUI Kabupaten Cianjur berdirilah sebuah pesantren yang diberi nama Pesantren terpadu At-Taubah di lembaga pemasyarakatan.

Sejak saat itu Pesantren terpadu At-Taaubah selain pesantren yang berdiri dalam sebuah lembaga pemasyarakatan juga menjadi program kerja dari pihak MUI Kab Cianjur sehingga pimpina pesantren dan Asatid dari MUI, bukan hanya itu kebutuhan Pesantren sebesar \pm Rp. 9.9 00.000 untuk transport para asatid dalam satu bulan dan biaya alat tulis untuk melaksanakan pembelajaran di pesantren, dari sejak berdirinya pesantren hingga sekarang MUI kab. Cianjur Mensupport sekaligus mensuplai pendanaan pesantren terpadu At-Taubah karena memang berdirinya pesantren terpadu AtTaubah Lapas II B Cianjur atas kerjasama pihak lapas dengan pemerintah kabupaten Cianjur yaitu Bupati Cianjur, MUI dan menjadi program kerja MUI Kab. Cianjur.

Masa pembinaan pesantren tidak lanjut bagi warga binaan yang masa hukumannya singkat. Masa hukuman yang berlaku bagi setiap warga binaan samngat bervariasi terggantung dengan kasus yang dihadapinya, dari yang hanya bulanan, tahunan, belasan tahun bahkan puluhan tahun. Bagi mereka yang meendapatkan hukuman selam empat tahun keatas mejadi kesempatan emas untuk fokus 
e-ISSN: 2686-0724 - p-ISSN: 0853-4470 - Vol. 02, No. 02 (2019), pp. 74-60 mengikuti kegiatan pesantren At-Taubah sampai mendapatkan ilmu yang benar-benar matang, memahami ilmu agama dan Alquran bahkan hafal dan tidak menutup kemungkinan mempunyai kesempatan untuk menjadi seorang ustad,dai bahkan sampai kiyai, terlebih lagi warga binaan yang hukumannya belasan sampai puluhan tahun.

Dengan solusi alumni pesantren dititipkan kepada asatid yang mempunyai pesantren di luar dan rencana pengelompokan warga binaan masa tahanan singkat untuk pembinaan. Untuk warga binaan yang hanya memiliki masa tahanan yang singkat dan tidak tuntasnnya pembinaan pesantren tentang akhlak dan moral dan tidak adanya kesinambungan kegiatan pesantren bagi warga binaan yang sudah menjadi alumni bukan berarti tidak ada jalan keluarnya, akan tetapi salah satu jalan keluar yang dilakukan oleh pihak pesantren dengan cara menitipkan alumni santri yang ingin melanjutkan pembinaan kepada asatid yang yang mempunyai pesantren dan santri diluar lapas.

Masalah badal asatid dari warga binaan dengan warga binaan lainnya. Pelaksanaan pembelajaran dalam satu kelas setiap asatid memegang dan fokus terhadap satu kelas, akan tetapi dalam pelaksaan kegiatan pesantren dalam kelas dari 27 kelas ada saja asatid yang berhalangan hadir, hingga akhirnya solusi dari pesantren adalah menjadikan santri atau warga binaan yang duduk di kelas eksekutif menjadi badal atau pengganti asatid yang tidak hadir, akan tetapi sekalipun warga binaan atau santri yang duduk di kelas eksekutif menjadi solusi dari permasalahan berhalangan hadirnya para asatid bukan berarti masalah beres, tapi muncul masalah baru, yaitu tidak terimanya sebagian warga binaan atau santri yang berada dikelas ketika digantikan asatidnya oleh santri lagi, karena merasa sama-sama mempunyai latar belakang yang sama yaitu seorang warga binaan.

Dengan solusi metode pendekatan emosional kepada warga binaan yang paling ditakuti untuk mempermudah pelaksanaan kegiatan pesantren yang dilakukan oleh badal asatid dari wargabinaan. Terjadinya penolakan dari santri untuk santri yang menjadi badal asatid tidak mematahkan para santri yang ditugaskan menjadi badal asatid, akan tetapi justru mereka mencari jalan untuk setiap permasalahan yang dihadapi, salah satu metode atau cara yang digunakan agar santri bisa mengikuti dan menerima kegiatan pesantren dalam kelas yang di pimpin oleh badal asatid adalah dengan cara santri yang menjadi badal asatid melakukan pendekatan dengan santri yang paling kuat, ditakuti dan berpengaruh yang berada dalam kelas (mereka menyebutnya Brengos yang ada dalam kelas ).

Pembinaan lapas terhadap warga binaan non muslim. Didirikannya Pesantren Terpadu AtTaubah dalam lembaga pemasyarakatan II B Cianjur merupakan perkembangan dari pembinaan kerohanian yang wajib dilakukan oleh setiap lembaga pemasyarakatan. Dengan solusi mendatangkan pembina non muslim dari luar. Khusus Untuk Warga Binaan Non Muslim, dari 744 warga binaan yang berada di lapas II B Cianjur mayoritas beragama Setiap hari rabu dan sabtu dengan mendatangkan pendeta bekerja sama dengan Badan Kerja Sama Antar Gereja (BKSAG) Kab. Cianjur dan Gereja Batel Bandung.

Konflik santri yang berkaitan dengan kegiatan pesantren adanya beberapa permasalahan santri yang berkaitan dengan kegiatan pesantren, diantaranya, terjadi keributan antara santri atau warga binaan, beberapa santri saling menjatuhkan untuk mendapatkan sebuah kekuasaan di pesantren, berbedanya metode asatid dalam pembelajaran, membuat santri memilih kelas yang lebih mudah.

Dengan solusi pemanggilan santri yang bermasalah dan rapat pengurus. Pesantren dala memecahkan masalah yang terjadi di pesantren, setiap ada permasalahan antara santri ataupun seluruh permasalahan yang terjadi dengan santri, maka jalan pertama yang ditempuh oleh pengurus pesantren adalah memanggil santri yang bermasalah, ketika permasalahan nya antara santri maka langkang pertama memanggil kedua santri yang bermasalah tersebut, lalu ditanya apa masalahnya dan 
diselesaikan secara kekeluargaan, begitupun masalah lainya, jika bisa diselesaikan dengan cara berdiskusi maka diselesaikan pada waktu itu juga.

Problem perbedaan latar belakang santri. Tujuan utama pesantren dalam jangka pendek yaitu menyadarkan santri agar bertaubat dan tidak mengulangi kejahatannya kembali, akan tetapi banyaknya santri dengan latar belakang yang heterogen masalah yang berbeda, lingkungan dan sosial yang berbeda, status pendidikan yang berbeda, terutama mereka masuk kedalam lapas karena sebuah kesalahan dan berbeda dengan pesantren di luar lapas yang santri datang ke pesantren tanpa paksaan dan atas kemauan dan kesadaran sendiri sehingga siap mengikuti seluruh kegiatan pesantren, akan tetapi santri di dalam lapas adalah santri yang dipaksa mengikuti kegiatan pesantren jika tanpa kesadaran maka sulit dalam pelaksanaannya membuat pesantren sulit menyadarkan para santri agar bertaubat.

Menjalankan kegiataan pesantren secara terus-menerus. Solusi dari masalah tersebut adalah dengan terus-menerus menjalankan kegiatan pesantren, dengan istigosah, riyadoh, dan pengajianpengajian lainnya sehingga membuat warga binaan tergugah dan sadar. Sulit diterima kembali alumni santri/mantan warga binaan dalam lingkungan masyarakat. Masyarakat berpandangan bahwa seorang mantan warga binaan adalah seseorang yang tidak bisa diterima kembali kehadirannya, karena masyarakat berpandangan bahwa mereka orang yang salah dan akan selalu salah sekalipun sudah mengikuti masa pembinaan ditahanan.

Dengan solusi memberikan sertifikat dan piagam penghargaan pesantren bagi santri yang bebas dari masa tahanan dan serah terima pihak pesantren dengan pihak pemerintah, tokoh agama, pemuda dan budaya di tempat tinggal alumni pesantren terpadu At-Taubah.

\section{KESIMPULAN}

Pesantren Terpadu At-Taubah Lembaga Pemasyarakatan Klas II B Cianjur dilatarbelakangi oleh keprihatinan petugas lapas dan sebagian warga binaan terhadap fenomena pembinaan keagamaan dalam Lembaga. Pesantren terpadu ini tercetus pada tanggal 13 Febuari 2012 dalam acara Maulid Nabi Muhammad SAW dan dilanjutkan dengan pembuatan M bersama tentang disepakatinya kegiatan pembinaan keagamaan di Lembaga Pemasyarakatan Klas II B Cianjur oleh MUI Kab. Cianjur berupa Pesantren Terpadu pada tanggal 16 April 2013 yang diprakarsai oleh Lembaga Pemasyarakatan Klas II B Cianjur, MUI Kab.Cianjur dan Para Pimpinan Pondok Pesantren se Kabupaten Cianjur.

Aktivitas dakwah di pesantren Terpadu At-Taubah terpusat pada dua dimensi dakwah yaitu dimensi kerisalahan (bi ahsan al-qawl) dan dimensi kerahmatan (bi ahsan al-amal). Dari seluruh kegiatan dakwah yang ada di pesantren maka dakwah dengan dimensi kerisalahan atau bi ahsan alqawl yang paling banyak dilaksanakan, seperti peringatan hari besar Islam, khutbah, riyadoh, istigosah, kajian tafsir Alquran dan lain-lain sedangkan dakwah bi Ahsan Al-amal hanya dengan manajemen pengelolaan zakat para santri.

Kendala yang terjadi dalam aktivitas dakwah di pesantren terpadu At-Taubah yang dikelompokan sesuai dengan dimensi dakwah yaitu dimensi kerisalahan atau bi ahsan al-qawl dan dimensi kerahmatan bi ahsan al-amal. dari semua kendala kebanyakan masalah ada pada dimensi kerahmatan atau bi ahsan al-amal, ialah pertama pendanaan dengan solusi bekerjasamanya Lapas II B Cianjur dengan MUI Kab. Cianjur, kedua pembinaan pesantren tidak lanjut bagi warga binaan dengan masa hukuman singkat dengan solusi alumni pesantren dititipakan kepada asatid yang memiliki pesantren dan perencanaan pengelompokan warga binaan yang hukumannya singkat.

Ketiga masalah badal asatid oleh warga binaan dengan solusi pendekatan terhadap brengos di kelas, keempat pembinaan lapas terhadap warga binaan non muslim dengan solusi mendatangkan 
e-ISSN: 2686-0724 - p-ISSN: 0853-4470 - Vol. 02, No. 02 (2019), pp. 74-60 pembina non muslim dari luar. Sedangkan masalah pada dimensi kerisalahan bi ahsan al-qawl adalah pertama terjadinya konflik santri dengan solusi pemanggilan santri bermasalah dan rapat pengurus dalam pemecahan masalah, kedua problem perbedaan latar belakang santri dengan solusi menjalankan kegiatan pesantren secara terus menerus dan ketiga sulit diterima kembali alumni santri atau mantan warga binaan oleh masyarakat dengan solusi pemberian sertifikat dan pengantaran ke rumah oleh pihak pesantren.

\section{DAFTAR PUSTAKA}

Abu, M. (2010) Ilmu Dakwah Prinsip Dan Kode Etik. Pondok Bambu: Akademika Pressindo.

Damopoli, M. (2011) Pesantren Modern IMMIM Pencetak MuslimModern. Jakarta:PT Raja Grafindo Persada.

Dhofier,H. (2011) Tradisi Pesntren. Jakarta: LP3ES.

Enjang dan Tajiri, H. (2009) Etika Dakwah. Bandung: Widya Padjajaran.

Enjang dan Aliyudin. (2009) Dasar-Dasar Ilmu Dakwah. Bandung: Widya Padjajaran.

Fatoni, U., \& Tedi, E. (2018). Dakwah Literasi Ustadz Giovani Van Rega: Analisis Imbauan Pesan Dakwah. Jurnal Komunikasi Islam, 7(2), 209-225.

Galba, S (1995) Pesantren Sebagai Wadah Komunikasi. Jakarta: PT Rineka Cipta.

Haedari, A dan Hanif, A (2004) Masa Depan Pesanntren. Jakarta: IRD press.

Ilahi,W (2010) Komunikasi Dakwah.Bandung :Simbiosa Rekatama Media.

Ismail, N., Abidin, Z., \& Fatoni, U. (2018). Pesan Dakwah tentang Nikah di Media Sosial Instagram.

Tabligh: Jurnal Komunikasi dan Penyiaran Islam, 3(1), 22-45.

Kusnawan, A (2016) Teknik Menulis Naskah Dakwah. Bandung: Simbiosa Rekatama Media.

Kusnawan,A. dkk. (2009) Dimensi Ilmu Dakwah. Bandung: Widya Padjajaran.Mastuhu. (1994) Dinamika Sistem Pendidikan Pesantren. Jakarta: INIS.

Masyhud,S dan Khusnurdilo, M (2005) Manajemen pondok pesantren. Jakarta: Diva

Pustaka

Natsir, M. (1987) Fiqhud-Dakwah. Solo: Cv. Ramdhani. Erlangga.

Qomar, M (2008) Pesantren Dari Transformasi Metodologi Menuju Demokratisasi Institusi. Jakarta:

Tajiri, H. (2015) Etika dan Estetika Dakwah. Bandung: Simbiosa Rekatama Media.

Maghfiroh, E (2016). Komunikasi Dakwah; Dakwah Interaktif Melalui Media Komunikasi:Dakwatuna: Jurnal Dakwah dan Komunikasi Islam ,2(1), 34:48.

Markarma,A. (2014) Komunikasi Dakwah Efektif dalam Perspektif Alquran: Jurnal Studia Islamika, 11(1), 127-151.

Ma'arif. S. (2009). Pola Komunikasi Dakwah KH. Abdullah Gymnastiar dan KH. Jalaluddin Rakhmat : Mimbar XXV (2), 161-180.

Hidayanti, A. (2016). Metode Dakwah dan Bimbingan Sunan Kalijaga.Surat Skripsi, Jurusan Bimbingan dan Konseling Islam, UIN Sunan Gunung Djati, Bandung.

Shofi. A. (2010). Aktivitas Dakwah K.H Muhyiddin Naim Melalui Masjid Al-Akhyar Kemang Jakarta Selatan. UIN Syarif Hidayatullah, Jakarta.

Supriyadi.H. (2014). Pembinaan Agama Islam Sebagai Upaya Pengurangan Terjadinya Pengulangan Tindak Pidana Bagi Narapidana Di Lembaga Pemasyarakatan Klas II B Cianjur. Uin Syarif Hidayatullah, Jakarta. 